\title{
Feeding ecology of Eigenmannia desantanai (Gymnotiformes: Sternopygidae) in southern Pantanal, Brazil
}

\author{
Ecologia alimentar de Eigenmannia desantanai (Gymnotiformes: Sternopygidae) no \\ Pantanal Sul, Brasil
}

\section{Élida Jeronimo Gouveia ${ }^{1}$ (D), Patrícia Luna Rondon ${ }^{2}$ (D), Yzel Rondon Súarez ${ }^{3 *}$ (D)}

\author{
${ }^{1}$ Programa de Pós Graduação em Ecologia de Ambientes Aquáticos Continentais, Universidade \\ Estadual de Maringá - UEM, Núcleo de Pesquisa em Limnologia, Ictiologia e Aquicultura - \\ Nupélia, H90, CEP 87020-900, Maringá, PR, Brasil \\ ${ }^{2}$ Programa de Pós Graduação em Ecologia e Conservação, Universidade Federal de Mato Grosso do \\ Sul - UFMS, Av. Costa e Silva, s/nº, CEP 79070-900, Campo Grande, MS, Brasil \\ ${ }^{3}$ Laboratório de Ecologia, Centro de Estudos em Recursos Naturais - CERNA, Universidade \\ Estadual de Mato Grosso do Sul - UEMS, Rod. Dourados-Itahum, Km 12, CEP 79804-970, \\ Dourados, MS, Brasil \\ *e-mail: yzel@uems.br
}

Cite as: Gouveia, E.J., Rondon, P.L. and Súarez, Y.R. Feeding ecology of Eigenmannia desantanai (Gymnotiformes: Sternopygidae) in southern Pantanal, Brazil. Acta Limnologica Brasiliensia, 2022, vol. 34, e2.

Abstract: Aim: This study investigated changes in the dietary composition and trophic niche breadth of Eigenmannia desantanai in the context of hydrological periods, rivers, and ontogeny. Methods: Collections were performed monthly on the Paraguay and Amonguijá Rivers between February 2009 and January 2011. Results: A total of 338 specimens of E. desantanai were collected, 224 of which came from the Amonguijá River and 114 from the Paraguay River. In all, 21 food items were identified. Fully remains of digested animals (RDA), Chironomidae, Cladocera, and Ostracoda showed greater importance in the diet of $E$. desantanai. Dietary composition was influenced by hydrological periods, followed by differences between sampled rivers, and ontogeny. In contrast, only hydrological periods explained variation in the $E$. desantanai trophic niche breadth. Conclusions: The diet of $E$. desantanai is mainly composed of Chironomidae, Cladocera, and Ostracoda; however, individuals consumed other food items owing to changes in hydrological periods, followed by characteristics of the Amonguijá and Paraguay Rivers and ontogenetic variation. In this respect, the results of this study are germane to the food ecology of $E$. desantanai, providing guidelines for the management and conservation of the species.

Keywords: diet; tuvira; floodplain; Paraguay River; Amonguijá River.

Resumo: Objetivo: $\mathrm{O}$ estudo buscou investigar se as mudanças na composição da dieta e na amplitude de nicho trófico de Eigenmannia desantanai podem ser explicadas pelos períodos hidrológicos, rios e/ou ontogenia dos peixes. Métodos: As coletas foram realizadas mensalmente nos rios Paraguai e Amonguijá, entre Fevereiro de 2009 a Janeiro de 2011. Resultados: Foram coletados 338 exemplares de E. desantanai, sendo 224 do Rio Amonguijá e 114 do Rio Paraguai. Ao todo, foram identificados 21 itens alimentares. Restos de animais digeridos (RAD), Chironomidae, Cladocera e Ostracoda apresentaram maior importância na dieta de E. desantanai. A composição da dieta foi influenciada pelos períodos hidrológicos, seguida pelas diferenças dos rios amostrados e da ontogenia. 
Em contrapartida, apenas os períodos hidrológicos explicaram a variação na amplitude do nicho trófico de $E$. desantanai. Conclusóes: A dieta de $E$. desantanai é composta principalmente por Chironomidae, Cladocera e Ostracoda, no entanto, os indivíduos consumiram outros alimentos devido às mudanças dos períodos hidrológicos, seguida das características dos rios Amonguijá e Paraguai e da variação ontogenética. Neste contexto, os resultados deste estudo são pertinentes à ecologia alimentar de $E$. desantanai, fornecendo diretrizes para o manejo e conservação da espécie.

Palavras-chave: dieta; tuvira; planície de inundação; Rio Paraguai; Rio Amonguijá.

\section{Introduction}

The Neotropical region has a highly diversified fish fauna and, consequently, diversity of life forms and life history. A striking characteristic of Neotropical fish fauna is food plasticity (Abelha et al., 2001) since fish diet may vary according to ontogeny (Dias et al., 2017a), phenology (Cunha et al., 2018), as well as intra/ interspecific interactions (Silva et al., 2017).

In dynamic and productive environments, such as the Pantanal, the flood pulse is the main determinant of the structure and function of aquatic communities (Junk et al., 1989). Particularly in this system, hydrological variation throughout the year directly interferes with the availability and variety of food items, which consequently leads to changes in the fish diet (Ferreira et al., 2014; Scanferla \& Súarez, 2016). The aquatic macrophytes that colonize this floodplain also play an important role in the complexity and heterogeneity of environments (Thomaz \& Cunha, 2010; Dias et al., $2017 \mathrm{~b}$ ), providing shelter for insects, mollusks, periphyton, and fish (Silva et al., 2009; Saulino $\&$ Trivinho-Strixino, 2014), influencing the food chain (Grzybkowska et al., 2018).

Among the fish species existing in this floodplain, Eigenmannia desantanai belongs to the order Gymnotiformes and lives associated with macrophytes. It was previously identified as E. trilineata Lopez \& Castello, 1996, and recently described by Peixoto et al. (2015) occurring in the Pantanal basins of the Cuiabá and Paraguay Rivers (Pacheco \& Da-Silva, 2009; Súarez et al., 2013). In this region, E. desantanai is considered an important economic resource, as it is used as live bait by professional fishermen (Resende et al., 2006), and from an ecological point of view, it is an important source of food for large fish, thus contributing to the maintenance of floodplain fishes (Gimenes et al., 2013).

Knowledge about the trophic ecology of this species is restricted only to the North Pantanal and with few analyzed individuals (Santos et al., 2009; Corrêa et al., 2011; Ximenes et al., 2011), being that in the southern portion of the Pantanal, the species diet is unknown. Then, we have no data about spatial, temporal, and ontogenetic variation in feeding resource use in a seasonal environment as the Pantanal. In this sense, to expand knowledge in this area, the present study aimed to investigate changes in the feeding composition and trophic niche breadth of Eigenmannia desantanai among hydrological periods, rivers, and ontogeny.

\section{Material and Methods}

\subsection{Study area}

The study was carried out in the southern portion of the Pantanal, municipality of Porto Murtinho, Mato Grosso do Sul State, Brazil (Figure 1). Fish collection was carried out in the Paraguay and Amonguija rivers, which have different characteristics in terms of environmental heterogeneity, more specifically, the Paraguay River is the main watercourse of the Pantanal and approximately $300 \mathrm{~m}$ wide in the study area. It has a flow of around $0.81 \mathrm{~m} . \mathrm{s}^{-1}( \pm 0.36 \mathrm{SD})$, and on the margins, there are banks of macrophytes Eichhornia azurea (Swartz) Kunth, Polygonum ferrugineum Wedd., and Urochloa subquadripara (Trin.) R.D.Webster. The Amonguijá River is a tributary of the Paraguay River. It is about $40 \mathrm{~m}$ wide with a slower flow $\left(0.20 \pm 0.23 \mathrm{~m} \cdot \mathrm{s}^{-1}\right)$. The sampled section has approximately $50 \%$ of its bed covered by E. azurea, E. crassipes (Mart.) Solms, and P. ferrugineum, among other species of macrophytes.

The flood pulse is considered monomodal, and in the studied region, the peak occurs in the months of May, June, and July. Thus, the collection months were categorized as dry, rising-water, flood, and falling-water.

\subsection{Data collection}

The collections were performed monthly, during the day, between February 2009 and January 2011 (Authorization - SISBIO 13458-1). The locations were randomly defined along the river banks and on the macrophyte banks. To capture fish, rectangular sieves $(0.8 \times 1.2 \mathrm{~m})$ and seines $(1.5 \times 5 \mathrm{~m})$ were used, both with a $2 \mathrm{~mm}$ mesh, performed by two people. The fish were anesthetized with $10 \mathrm{mg} / \mathrm{L}$ of Eugenol, packed in plastic bags, 


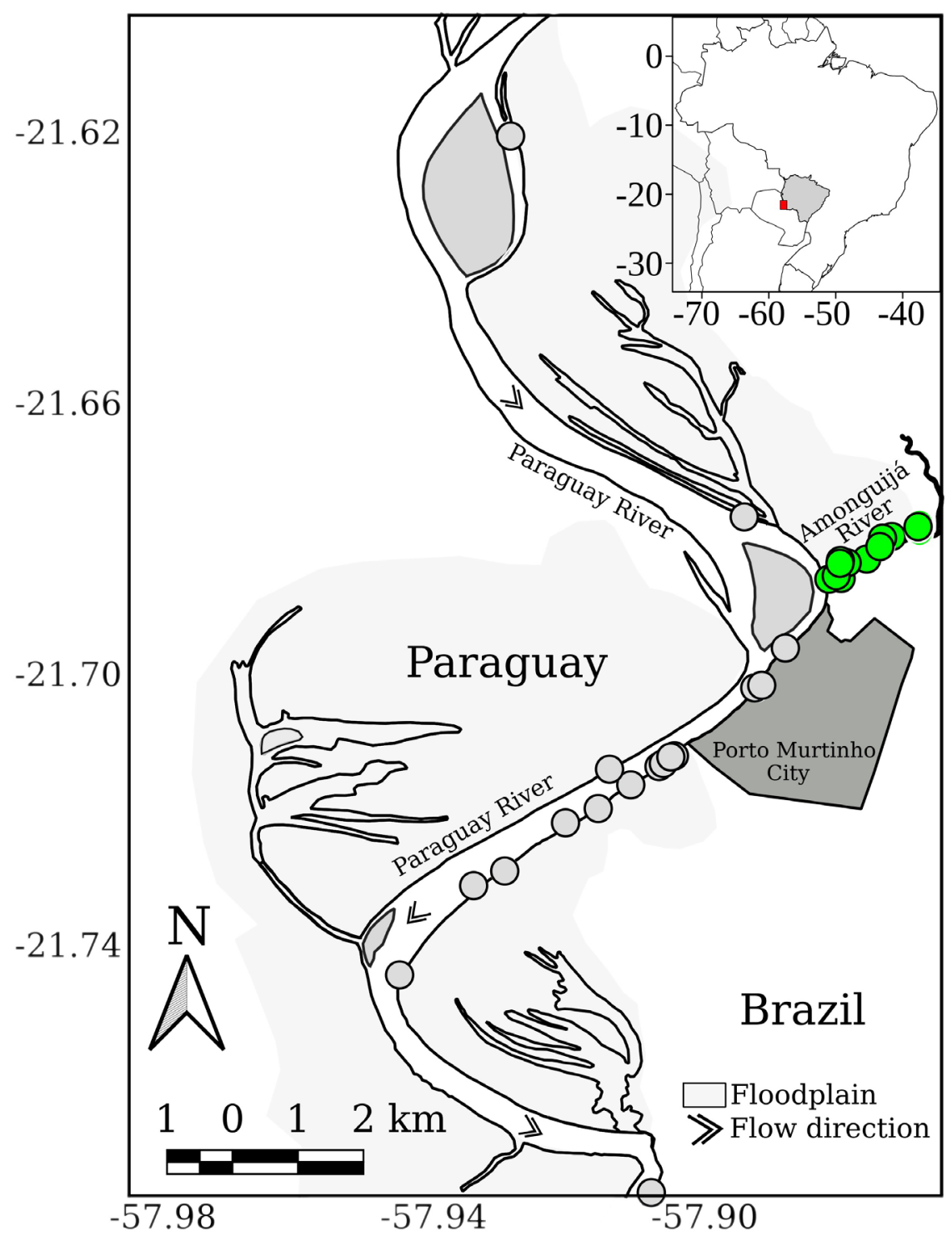

Figure 1. Location of sampling points along the Amonguijá (green circles) and Paraguay (gray circles) Rivers in the southern Pantanal, Porto Murtinho, MS, Brazil.

labeled, and fixed in formaldehyde (10\%). In the laboratory, the fish were preserved in ethanol (70\%). Weight $(\mathrm{g})$, head height, total length, and standard length $(\mathrm{mm})$ of each individual were measured, and then the stomach was removed.

\subsection{Stomach analysis}

Stomach contents were weighed in grams to the nearest 0.0001 and analyzed using a stereomicroscope and microscope. Food items were identified with the help of specific keys by McCafferty (1981), Stehr (1987), and Mugnai et al. (2010) and then quantified by the Volumetric Method and Frequency of Occurrence (Hynes, 1950; Hyslop, 1980). The Food Importance Index (IAi) was also estimated as $I A i=F i x V i / \sum_{i=1}^{n}(F i x V i)$, where $I A i=$ food index, $i=$ $1,2 \ldots, n=$ certain food item, $F i=$ food item occurrence frequency (\%), and $V i=$ food item volume (\%) (Kawakami \& Vazzoler, 1980).

Food items were grouped into different categories, such as remains of digested animals (RDA) composed of animal partially or totally digested; Chironomidae; Ostracoda; Cladocera; and Others, which was composed of items that presented low volume and occurrence, being Acarina, Amphipoda, Annelida, Araneae, Coleoptera, Copepoda, Concostracoda, Ephemeroptera larvae, Gastropoda, Culicidae larvae, Megaloptera, 
Nematoda, Odonata, Rotifera, Trichoptera, Filamentous Algae, and seeds.

\subsection{Data analysis}

In order to assess possible variations in dietary composition among hydrological periods, sites, and ontogeny, Permutational Multivariate Analysis of Variance (PERMANOVA) with the Bray-Curtis Coefficient (9999 permutations) was used. This analysis was carried out using a routine "adonis" in the vegan package (Oksanen et al., 2016).

The hydrological periods were defined according to the samples collected in the different months and rivers level, i.e., from February to April (Risingwater), from May to July (Flood), from August to October (Falling-water), and from November to January (Dry). The rivers (Paraguay and Amonguijá) were used as explanatory variables (factor) to infer if their characteristics (width, depth, velocity, aquatic macrophytes abundance) can change prey availability and consequently diet composition. To investigate ontogenetic effects, we used head height measurements in order to represent size variation over the life cycle, because the partial predation of the final portion of the body of Eigenmannia specimens may impede the use of body length as a proxy of fish age.

The Threshold Indicator Taxa ANalysis (TITAN) was used to detect food items considered indicators of the sampled months and the ontogeny of individuals. This analysis is based on the indicator value (Indval) scores (Dufrêne \& Legendre, 1997). For this analysis, the "titan" function included in the "TITAN2" package was used (Baker \& King, 2010; Baker et al., 2015).

The Levins coefficient (spaa package) was used to estimate the amplitude of the trophic niche for each fish. A covariance analysis was applied to verify the possible influence of the hydrological periods, rivers and head height $(\log )$ on niche breadth of the fish. The covariance analysis was also used to evaluate spatial, temporal and ontogenetic effect on volume of feeding items in stomach. All statistical analyses were performed on the R platform (R Development Core Team, 2021).

\section{Results}

A total of 338 individuals were analyzed, 224 (total length from 29.46 to $149.82 \mathrm{~mm}$ ) from the Amonguijá River and 114 fish (total length from 60.23 to $175.85 \mathrm{~mm}$ ) from the Paraguay River. Considering both rivers, head height varied from 4 to $21.47 \mathrm{~mm}$ (median $=12.96 \mathrm{~mm}$ ). Of these, 330 fish had some stomach contents.
The diet was composed of 21 food items, and those most important were Chironomidae $($ IAiAmonguijá $=28.9 \%$, IAiParaguay $=29.96 \%$, Cladocera (IAiAmonguijá = 22.7\%, IAiParaguay = $16.6 \%$ ), and Ostracoda (IAiAmonguijá = 5.84\%, IAiParaguay $=8.06 \%$ ). The remains of digested animals (RDA) represented the majority of the diet in both environments (IAiAmonguijá $=35.14 \%$, IAiParaguay $=39.62 \%)$. Other items contributed a lower food index and, thus, were grouped into a category designated as Others (IAiAmonguijá = $7.42 \%$, IAiParaguay $=5.76 \%)($ Figure 2$)$.

Considering food intake by individuals of $E$. desantanai, ANCOVA results showed that they varied among rivers $(\mathrm{F}=7.29 ; \mathrm{p}=0.007)$, river levels $(\mathrm{F}=$ 16.51; $\mathrm{p}<0.001)$ and fish head height $(\mathrm{F}=57.71 ; \mathrm{p}$ $<0.001)$. Food intake was higher in the Amonguijá river, in the flooding The diet composition of $E$. desantanai varied significantly between hydrological periods (PERMANOVA: $F=8.16 ; \mathrm{p}<0.001$ ), between rivers $(\mathrm{F}=6.21 ; \mathrm{p}<0.001)$ and head height $(\mathrm{F}=4.84 ; \mathrm{p}<0.001)$. Thus, the main determinant for variation in the diet was season, followed by differences between the Paraguay and Amonguijá Rivers, and the fish head height (Figure 3).

The TITAN analysis detected the items Copepoda, Nematoda, and Cladocera as indicators from January to June (late dry and rising-water), and the fallingwater period as marked by higher consumption of RDA, Ephemeroptera larvae, and Trichoptera. The item Araneae was consumed during the whole year, however in low abundance (Figure 4).

This analysis also showed that some items were preferentially consumed according to fish size, for example, the Rotifera and RDA categories were indicative of individuals with a head height between 10 to $13 \mathrm{~mm}$, whereas the larvae of Ephemeroptera, Culicidae, and Copepoda were predominantly consumed by larger fish (Figure 5).

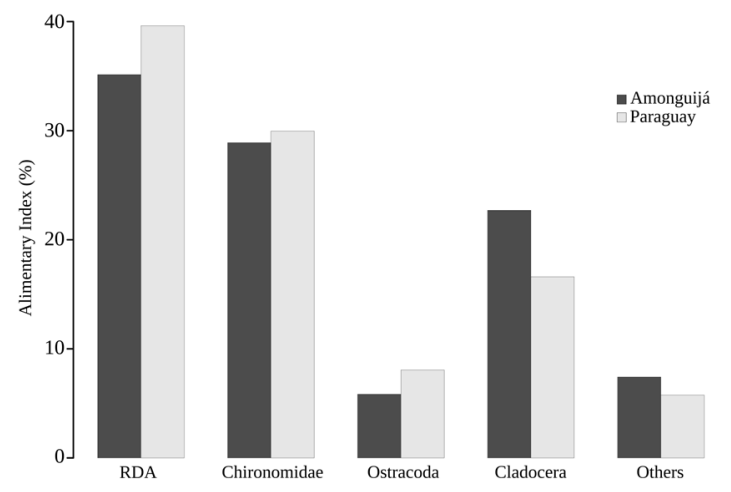

Figure 2. Alimentary Index for Eigenmannia desantanai in the Amonguijá and Paraguay Rivers at Porto Murtinho, MS, southern Pantanal, Brazil. 

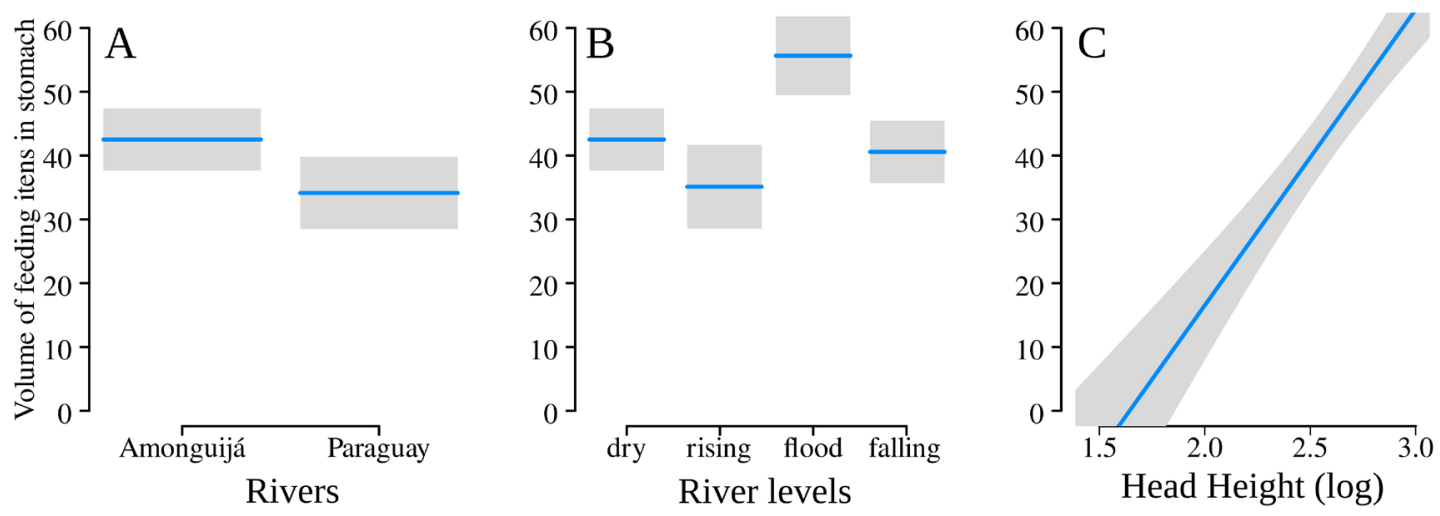

Figure 3. Food intake by Eigenmannia desantanai in southern Pantanal in function of sampled river (A), river water levels (B) and (C) fish size (head height).

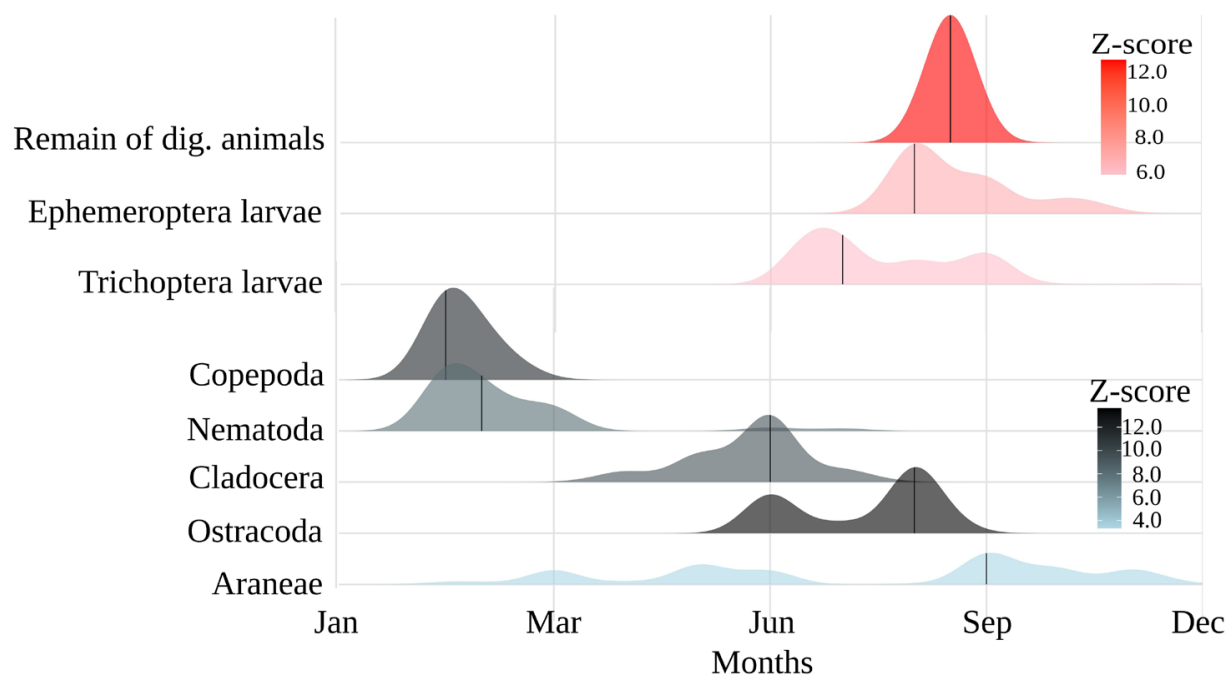

Figure 4. Variation of Eigenmannia desantanai food items over the months based on Threshold Indicator Taxa Analysis. The higher the value of the Z-score, the better the indication of the item.

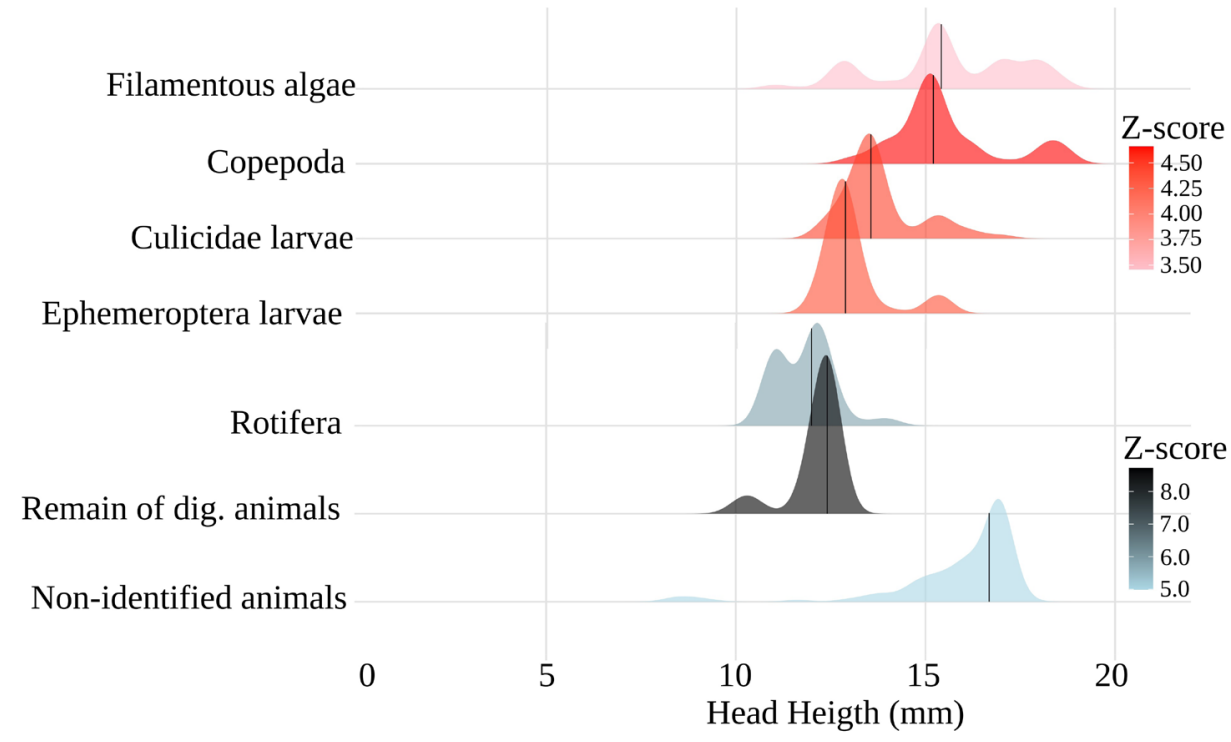

Figure 5. Variation of Eigenmannia desantanai food items along ontogeny based on Threshold Indicator Taxa Analysis. The higher the value of the Z-score, the better the indication of the item. 

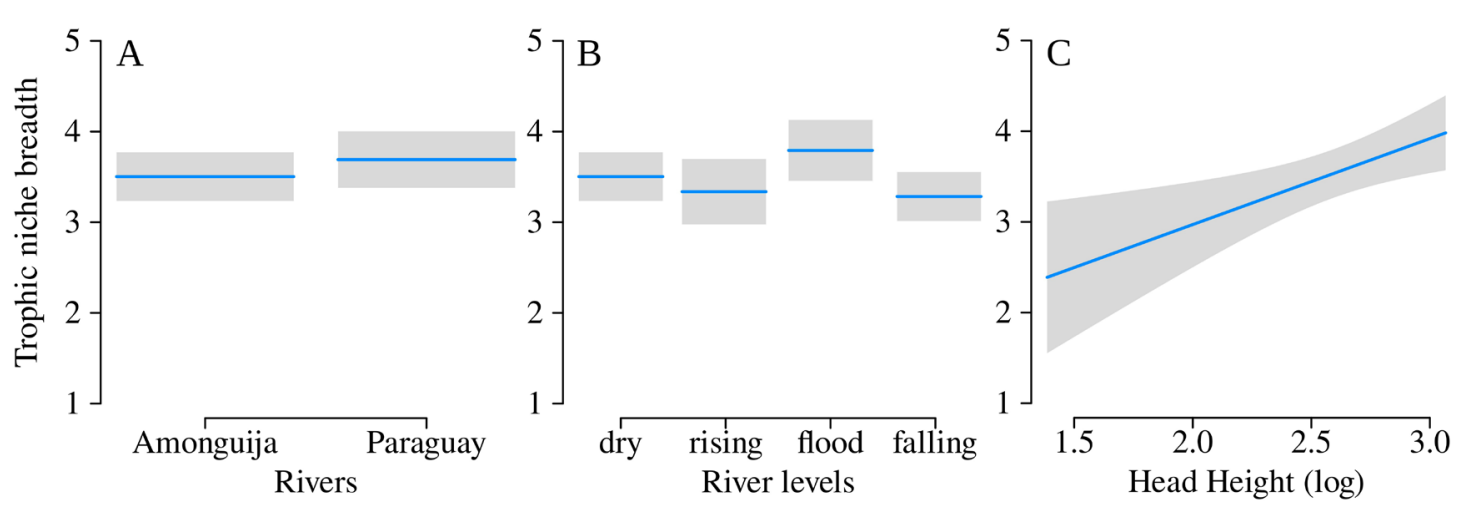

Figure 6. Trophic niche breadth for Eigenmannia desantanai. A) Amonguijá and Paraguay Rivers, B) Hydrological periods and C) Head height, at Porto Murtinho, MS, southern Pantanal, Brazil.

The trophic niche breadth of $E$. desantanai was influenced by the river level (ANCOVA: $\mathrm{F}=3.76$; $\mathrm{p}=0.01)$ and head height $(\mathrm{F}=7.97 ; \mathrm{p}<0.01)$. However rivers did not influence trophic niche breadth $(\mathrm{F}=2.84 ; \mathrm{p}=0.09)$ (Figure 6$)$. Then, a wider niche breadth was recorded in larger fish and during the flooding period.

\section{Discussion}

Eigenmannia desantanai lives associated with macrophyte banks (e.g Eichhornia crassipes, E. azurea, Polygonum ferrugineum and Urochloa subquadripara) that offer shelter and food resources through the roots to various organisms (e.g Hyphessobrycon eques, Odontostilbe spp., Pyrrhulina australis, Prionobrama paraguayensis) (Pacheco \& Da-Silva, 2009; Súarez et al., 2013), thus, the items identified in the stomach are a reflection of the habitat of this species. The diet was composed of both animal and plant materials, with especial reference to Chironomidae, Cladocera, and Ostracoda, being ingested in a similar way among fish from the Amonguijá and Paraguay Rivers. Similar results were obtained in other studies (Peretti \& Andrian, 1999; Pelicice \& Agostinho, 2006; Brandão-Gonçalves et al., 2010; Dias et al., 2017a) in which they found that the diet E. trilineata was based on aquatic insects (Chironomidae), terrestrial insects (Orders Diptera, Coleoptera, Odonata, Hymenoptera), zooplankton (Ostracoda, Cladocera) and sediments. The high content of remains of digested animals (RDA) in the stomach of $E$. desantanai samples can be explained by the crepuscular and nocturnal behavior of the genus Eigenmannia (Mago-Leccia, 1994). Collections occurred during the day, and it is likely that prey items were already undergoing digestion.
The category others was considered accidental, or additional, at certain times of the year. These results are consistent with the Optimal Foraging Theory, which predicts that predators tend to maximize gains and reduce energy costs associated with obtaining resources, taking into account several factors, such as energy cost, satiety, and, above all, the availability of food resources (MacArthur \& Pianka, 1966). Thus, this variety of accidental items mat represent a strategy used by $E$. desantanai to meet its energy demands when its main food sources are in short supply (Dill, 1983). Duarte et al. (2019) studied the diet of Sternarchella calhamazon (Order Gymnotiformes) in the Purus River (Amazon Basin) and demonstrated that the ingestion of various food items at low frequency resulted from availability, not food preference, since the environment changes seasonally. This same hypothesis can explain the number of low frequency of several prey items in the diet of E. desantanai.

Differences in food intake between sampled rivers, river level and fish size (in our case using head height) are expected due to environmental differences in a dynamic environment as floodplain rivers. The Amonguijá river presents higher coverage of aquatic macrophytes and lower water velocity when compared to the Paraguay river, then, it is likely that feeding availability (or simply ease to capture) is higher and competitive interactions relaxed. These hypotheses are consistent with some theoretical expectation about resource partitioning when more "adequate" habitats offer more quantity/ quality of resources (Correa e Winemiller, 2014). Other important results indicated higher food intake during the flood season and by larger fish, once the increase of available area for feeding (in the flood period) also offer new habitats for foraging by E. desantanai. Larger fishes also have a larger mouth 
and consequently they can consume prey that is not available for smaller individuals; moreover, they have higher energy requirements to maintain their metabolism (Quirino et al., 2017; Cavalheiro \& Fialho, 2019).

Season influenced dietary composition, and it was the main predictor of trophic niche breadth for E. desantanai. In periods of late dry and rising-water, the diet was represented by Copepoda, Nematoda, and Cladocera. On the other hand, in the period of falling-water, we observed a predominance of RDA, Ephemeroptera larvae, and Trichoptera. This trophic flexibility is the result of species adaptation to oscillation in the availability of prey in a floating environment (Uieda \& Pinto, 2011), as is the case of the Pantanal. This pattern of alternation in the diet is expected for fish that inhabit environments subject to hydrological changes. Moreover, as each prey species responds differently to seasonal variation, the predator depends on the plasticity of food resources for survival. This variation in dietary composition has already been reported in other fish species in floodplains (e.g., Ximenes et al., 2011; Quirino et al., 2015; Scanferla \& Súarez, 2016; Costa-Pereira et al., 2017).

Spatial variation in dietary composition suggests that differences in the structure of the sampled habitats may influence the food supply for $E$. desantanai. For example, Chironomidae and Ostracoda were more abundant in the Paraguay River, while Cladocera and Other items were more abundant in the Amonguijá River. Evidence supports that macrophyte banks can retain zooplankton organisms in floodplain environments (Hamilton et al., 1990) wherein ponds with high macrophyte coverage can have a density of zooplankton up to 100 times greater than that of rivers. In this study, the difference between these environments with greater macrophyte coverage and lower current speed in the Amonguijá River may lead to a higher zooplankton density, changing its supply and, consequently, consumption by fish. On the other hand, results did not show differences in niche breadth between sampled rivers. Then, food intake and diet composition differ between Amonguijá and Paraguay rivers, however trophic niche breadths are similar. Our results suggest that despite higher flood intake and different prey compositions in the Amonguijá river, the number of prey and proportional distribution among them is statistically equal when compared to the Paraguay river.

Ontogenetic variation in the feeding of Eigenmannia has already been evaluated (e.g., Giora et al., 2005, for E. trilineata). It was found that juveniles feed mainly on microcrustaceans, digested organic material, and autochthonous insects, while adults consume mainly the last two food items mentioned. Similar results for other fish species have also been found (e.g., Dias et al., 2017a; Barreto et al., 2008). These dietary differences result from differences in energy requirements and morphological limitations (Abelha et al., 2001). This change in dietary composition throughout ontogeny could also be a strategy to minimize the overlap of trophic niche between different age groups for $E$. desantanai. Other studies have reported on the sharing of food resources in fish (Zaret \& Rand, 1971; Brito et al., 2019). Therefore, in addition to being influenced by the morphometric characteristics of the organisms, dietary changes throughout ontogeny can also be explained by differences in energy content, as well as by mechanisms to avoid intraspecific competition. Here, it is worth mentioning that although we detected ontogenetic variation in the preference of food items, the absence of smaller individuals in our samples impeded the investigation of the diet of small immature fish.

In conclusion, our data showed that Chironomidae, Cladocera, and Ostracoda were the main resources in the diet of $E$. desantanai. Dietary composition was strongly influenced by temporal variation, followed by variation between Paraguay and Amonguijá Rivers and then by ontogeny. Therefore, the results of this study are germane to the food ecology of $E$. desantanai, providing guidelines for the management and conservation of the species, which is considered a key economic resource in the studied region.

\section{Acknowledgements}

We are grateful to Conselho Nacional de Desenvolvimento Científico e Tecnológico (CNPq), FUNDECT and Centro de Pesquisas do Pantanal (CPP) for financial support. We are also grateful for many persons that contributed with logistical support in the field and laboratory. Y. R. Súarez is supported by productivity grants from $\mathrm{CNPq}$.

\section{References}

Abelha, M.C.F., Agostinho, A.A., \& Goulart, E., 2001. Plasticidade trófica em peixes de água doce. Acta Sci Biol Sci. 23(2), 425-434. https://doi.org/10.4025/ actascibiolsci.v23i0.2696.

Baker, M.E., \& King, R.S., 2010. A new method for detecting and interpreting biodiversity and ecological community thresholds. Methods Eco. 
Evol. 1(1), 25-37. https://doi.org/10.1111/j.2041210X.2009.00007.x.

Baker, M.E., King, R.S. \& Kahle, D., 2015. TITAN2: Threshold indicator taxa analysis. Version 2.4.1. Vienna: R Foundation for Statistical Computing.

Barreto, S.B., Silva, A.T., Souza, F.B., \& Jucá-Chagas, R., 2008. Diet of Hemigrammus marginatus (Characiformes: Characidae) in the Upper Contas River, Diamantina Plateau (Bahia, Brazil). Iheringia, Sér Zool. 108, e2018036. https://doi. org/10.1590/1678-4766e2018036.

Brandão-Gonçalves, L., Oliveira, S.A., \& Lima-Junior, S.E., 2010. Hábitos alimentares da ictiofauna do Córrego Franco, Mato Grosso do Sul. Biota Neotrop. Online 10(2), 21-30. http://dx.doi.org/10.1590/ S1676-06032010000200001.

Brito, G.J.S., Lima, L.G., Oliveira, R.E.M.C.C., \& Pessanha, A. 2019. Intraspecific food resource partitioning in Brazilian silverside Atherinella brasiliensis (Atheriniformes: Atherinopsidae) in a tropical estuary, Brazil. Neotrop. Ichthyol. 17(2), e180108. http://dx.doi.org/10.1590/1982-022420180108.

Cavalheiro, L.W., \& Fialho, C.B., 2019. Ontogeny of feeding by Astyanax paris in streams of the Uruguay River Basin, Brazil. Anim. Biodivers. Conserv. 42(1), 1, 9-18. http://dx.doi.org/10.32800/ abc.2019.42.0009.

Corrêa, C.A., Albrecht, M.P., \& Hahn, N.S., 2011. Patterns of niche breadth and feeding overlap of the fish fauna in the seasonal Brazilian Pantanal, Cuiabá River basin. Neotrop. Ichthyol. 9(3), 637-646. http:// dx.doi.org/10.1590/S1679-62252011000300017.

Correa, S.B., \& Winemiller, K.O., 2014. Niche partitioning among frugivorous fishes in response to fluctuating resources in the Amazonian floodplain forest. Ecology. 95(1), 210-224. PMid:24649660. http://dx.doi.org/10.1890/13-0393.1.

Costa-Pereira, R., Tavares, L.E.R., Camargo, P.B., \& Araújo, M.S., 2017. Seasonal population and individual niche dynamics in a tetra fish in the Pantanal wetlands. Biotropica 49(4), 531-538. http:// dx.doi.org/10.1111/btp.12434.

Cunha, A.F., Wolff, L.L., \& Hahn, N.S., 2018. Seasonal changes at population and individual levels in the diet of juvenile catfish in a Neotropical floodplain. J. Freshwat. Ecol. 33(1), 273-284. http://dx.doi.org /10.1080/02705060.2018.1442371.

Dias, R.M., Silva, J.C.B., Gomes, L.C., \& Agostinho, A.A., 2017b. Effects of macrophyte complexity and hydrometric level on fish assemblages in a Neotropical floodplain. Environ. Biol. Fishes 100(6), 703-716. http://dx.doi.org/10.1007/s10641-017-0597-y.

Dias, T.S., Stein, R.J., \& Fialho, C.B., 2017a. Ontogenetic variations and feeding habits of a Neotropical annual fish from southern Brazil. Iheringia. Zool. 107, 1-15. https://doi.org/10.1590/1678-4766e2017020.

Dill, L.M., 1983. Adaptive flexibility in the foraging behavior of fishes. Can. J. Fish. Aquat. Sci. 40(4), 398-408. http://dx.doi.org/10.1139/f83-058.

Duarte, C., Magurran, A.E., Zuanon, J., \& Deus, C.P., 2019. Trophic ecology of benthic fish assemblages in a lowland river in the Brazilian Amazon. Aquat. Ecol. 53(4), 707-718. http://dx.doi.org/10.1007/ s10452-019-09720-5.

Dufrêne, M., \& Legendre, P., 1997. Species assemblages and indicator species: the need for a flexible asymmetrical approach. Ecol. Monogr. 67(3), 345366. http://dx.doi.org/10.2307/2963459.

Ferreira, F.S., Vicentin, W., Costa, F.E.S., \& Súarez, Y.R., 2014. Trophic ecology of two piranha species, Pygocentrus nattereri and Serrasalmus marginatus (Characiformes, Characidae), in the floodplain of the Negro River. Pantanal. Acta Limnol. Bras. Online 26(4), 381-391. http://dx.doi.org/10.1590/S2179975X2014000400006.

Gimenes, M.F., Fugi, R., Isaac, A., \& Silva, M.R., 2013. Spatial, seasonal and ontogenetic changes in food resource use by a piscivore fish in two Pantanal lagoons, Brazil. Neotrop. Ichthyol. 11(1), 163-170. http://dx.doi.org/10.1590/S167962252013000100019 .

Giora, J., Fialho, C.B., \& Dufech, A.P.S., 2005. Feeding habit of Eigenmannia trilineata Lopez \& Castello, 1966 (Teleostei: Sternopygidae) of Parque Estadual de Itapuâ, RS, Brazil. Neotrop. Ichthyol. 3(2), 291-298. http://dx.doi.org/10.1590/S167962252005000200007 .

Grzybkowska, M., Dukowska, M., Leszczyńska, J., Lik, J., Szczerkowska-Majchrzak, E., \& Przybylski, M., 2018. The food resources exploitation by smallsized fish in a riverine macrophyte habitat. Ecol. Indic. 90, 206-214. http://dx.doi.org/10.1016/j. ecolind.2018.02.021.

Hamilton, S.K., Sippel, S.J., Lewis Junior, W.M., \& Saunders 3rd, J.F., 1990. Zooplankton abundance and evidence for its reduction by macrophyte mats in two Orinoco floodplain lakes. J. Plankton Res. 12(2), 345-363. http://dx.doi.org/10.1093/ plankt/12.2.345.

Hynes, H.B.N., 1950. The food of Fresh-Water Sticklebacks (Gasterosteus aculeatus and Pygosteus pungitius), with a review of methods used in studies of the food of fishes. J. Anim. Ecol. 19(1), 36-58. http://dx.doi.org/10.2307/1570.

Hyslop, E.J., 1980. Stomach contents analysis - a review of methods and their application. J. Fish Biol. 17(4), 411429. http://dx.doi.org/10.1111/j.1095-8649.1980. tb02775.x.

Junk, W., Bayley, P.B., \& Sparks, R.E., 1989. The Flood Pulse Concept in River-Floodplain Systems. 
In: Proceedings of the International Large River Symposium (LARS). Ontario: Canada Department of Fisheries and Oceans, 110-127.

Kawakami, E., \& Vazzoler, G., 1980. Método gráfico e estimativa de índice alimentar aplicado no estudo de alimentação de peixes. Bol. Inst. Oceanogr. 29(2), 205-207. http://dx.doi.org/10.1590/S037355241980000200043 .

MacArthur, R.H., \& Pianka, E.R., 1966. On optimal use of a patchy environment. Am. Nat. 100(916), 603-609. http://dx.doi.org/10.1086/282454.

Mago-Leccia, F., 1994. Electric fishes of the continental waters of America. Caracas: Clemente Editores.

McCafferty, W.P. 1981. Aquatic entomology. Sudbury: Jones and Barlett.

Mugnai, R., Nessimian, J.L., \& Batista, D.F., 2010. Manual de identificação de macroinvertebrados aquáticos do estado do Rio de Janeiro. Rio de Janeiro: Technical Book.

Oksanen, J., Blanchet, F.G., Friendly, M., Kindt, R., Legendre, P., Mcglinn, D., Minchin, P.R., O’hara, R.B., Simpson, G.L., Solymos, P., Stevens, M.H.H., Szoecs, E., \& Wagner, H., 2016. Vegan: community ecology package. Version 2.4-1 [online]. Vienna: R Foundation for Statistical Computing. Retrieved in 2020, Set 14, from: http://CRAN.R-project.org/ package $=$ vegan .

Pacheco, E.B., \& Da-Silva, C.J., 2009. Fish associated with aquatic macrophytes in the Chacororé - Sinhá Mariana Lake system and Mutum River, Pantanal of Mato Grosso, Brazil. Braz. J. Biol. 69(1), 101-108. PMid:19347151. http://dx.doi.org/10.1590/S151969842009000100012 .

Peixoto, L.A.W., Dutra, G.M., \& Wosiacki, W.B., 2015. The Electric Glass Knifefishes of the Eigenmannia trilineata species-group (Gymnotiformes: Sternopygidae): monophyly and description of seven new species. Zool. J. Linn. Soc. 175(2), 384-414. http://dx.doi.org/10.1111/zoj.12274.

Pelicice, F.M., \& Agostinho, A.A., 2006. Feeding ecology of fishes associated with Egeria spp. patches in a tropical reservoir, Brazil. Ecol. Freshwat. Fish 15(1), 10-19. http://dx.doi.org/10.1111/j.16000633.2005.00121.x.

Peretti, D., \& Andrian, F., 1999. Feeding of Eigenmannia trilineata (Pisces, Sternopygidae) (Lopez \& Castello, 1966), in the upper Paraná River floodplain, Brazil. Braz. Arch. Biol. Technol. 42(1), 1-8. http://dx.doi. org/10.1590/S1516-89131999000100011.

Quirino, B.A., Carniatto, N., Gaiotto, J.V., \& Fugi, R., 2015. Seasonal variation in the use of food resources by small fishes inhabiting the littoral zone in a Neotropical floodplain lake. Aquat. Ecol. 49(4), 431440. http://dx.doi.org/10.1007/s10452-015-9535-2.

Quirino, B.A., Carniatto, N., Guglielmetti, R., \& Fugi, R., 2017. Changes in diet and niche breadth of a small fish species in response to the flood pulse in a Neotropical floodplain lake. Limnologica 62, 126-131. http:// dx.doi.org/10.1016/j.limno.2016.10.005.

R Development Core Team, 2021. R: a language and environment for statistical computing [online]. Vienna: R Foundation for Statistical Computing. Retrieved in 2021, July 25, from http://www.Rproject.org/

Resende, E.K., Pereira, R.A.C., Sório, V.F., \& Galvão, E.M., 2006. Biologia da tuvira, Gymnotus cf. carapo (Pisces, Gymnotidae) no baixo Rio Negro, Pantanal, Mato Grosso do Sul, Brasil. Bol. Pesq. Desenvolv. Embrapa 67, 1-42.

Santos, C.L., Santos, I.A., \& Silva, C.J., 2009. Ecologia trófica de peixes ocorrentes em bancos de macrófitas aquáticas na baia Caiçara, Pantanal Mato-Grossense. Rev. Bras. Biocienc. 7(4), 473-476.

Saulino, H.H.L., \& Trivinho-Strixino, S., 2014. Macroinvertebrados aquáticos associados às raízes de Eichhornia azuera (Swarts) Kunth (Pontederiaceae) em uma lagoa marginal no Pantanal, MS. Biotemas 27(3), 65-72. http://dx.doi.org/10.5007/2175$7925.2014 \mathrm{v} 27 \mathrm{n} 3 \mathrm{p} 65$.

Scanferla, A.F.L.S., \& Súarez, Y.R., 2016. Flood pulse are the main determinant of feeding dynamics and composition of Odontostilbe pequira (Characiformes: Characidae) in southern Pantanal, Brazil. Acta Limnol. Bras. Online 28, e19. http://dx.doi. org/10.1590/s2179-975x3316.

Silva, F.H., Favero, S., Sabino, J., \& Garnés, S.J.A., 2009 Distribuição da entomofauna associada às macrófitas aquáticas na vazante do rio Correntoso, Pantanal do Negro, Estado de Mato Grosso do Sul, Brasil. Acta Sci. Biol. Sci. 31(2), 127-134. http://dx.doi. org/10.4025/actascibiolsci.v31i2.1182.

Silva, J.C., Gubiani, É.A., Neves, M.P., \& Delariva, R.L., 2017. Coexisting small fish species in lotic neotropical environments: evidence of trophic niche differentiation. Aquat. Ecol. 51(2), 275-288. http:// dx.doi.org/10.1007/s10452-017-9616-5.

Stehr, F.W. 1987. Immature Insects. Dubuque: Kendall Hunt Publishing.

Súarez, Y.R., Ferreira, F.S., \& Tondato, K.K., 2013. Assemblage of fish species associated with aquatic macrophytes in Porto Murtinho Pantanal, Mato Grosso do Sul, Brazil. Biota Neotrop. 13(2), 182-189. http://dx.doi.org/10.1590/S167606032013000200017.

Thomaz, S.M., \& Cunha, E.R., 2010. The role of macrophytes in habitat structuring in aquatic ecosystems: methods of measurement, causes and consequences on animal assemblages' composition and biodiversity. Acta Limnol. Bras. Online 22(2), 218236. http://dx.doi.org/10.4322/actalb.02202011.

Uieda, V.S., \& Pinto, T.L.F., 2011. Feeding selectivity of ichthyofauna in a tropical stream: space-time 
variations in trophic plasticity. Community Ecol. 12(1), 31-39. http://dx.doi.org/10.1556/ ComEc.12.2011.1.5.

Ximenes, L.Q.L., Mateus, L.A.F., \& Penha, J.M.F., 2011. Variação temporal e espacial na composição de guildas alimentares da ictiofauna em lagoas marginais do Rio Cuiabá, Pantanal Norte. Biota Neotrop. 11(1), 205-215. http://dx.doi.org/10.1590/S167606032011000100022.
Zaret, T.M., \& Rand, A.S., 1971. Competition in tropical stream fishes: support for the competitive exclusion principle. Ecology 52(2), 336-342. http://dx.doi. org/10.2307/1934593.

Received: 19 October 2020 Accepted: 25 November 2021

Associate Editor: Fernando Mayer Pelicice. 